\title{
Short communication: Virulence profiles of Staphylococcus aureus isolated from bulk tank milk and adherences on milking equipment on Chilean dairy farms
}

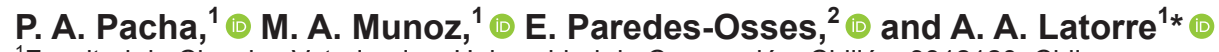 \\ ${ }^{1}$ Facultad de Ciencias Veterinarias, Universidad de Concepción, Chillán, 3812120, Chile \\ ${ }^{2}$ Instituto de Salud Pública, Department of Environmental Health, Ñuñoa, Santiago 7750000 , Chile
}

\begin{abstract}
Staphylococcus aureus is an important intramammary pathogen for dairy cows that also is remarkably important for public health. Multiple virulence factors can be involved simultaneously during the pathogenesis of a staphylococcal disease, including adhesion proteins, extracellular enzymes, and toxins. The main objective of this study was to assess virulence factors that are associated with cow intramammary infection (IMI) and of human health concern among Staph. aureus isolates obtained from bulk tank milk (BTM) and adherences on milking equipment surfaces. A total of 166 Staph. aureus isolates from 23 dairy farms were characterized according to their virulence profiles. For virulence factors of importance in IMI, the presence of the virulence markers thermonuclease (nuc) and coagulase (coa) and virulence genes such as fibronectin $(f n b \mathrm{~A})$ and intercellular adhesion $(i c a A, i c a D)$ were assessed. For virulence factors of public health concern, presence of antimicrobial resistance $(m e c A$ and $m e c C)$ and enterotoxin (sea and seb) genes were analyzed. Among all Staph. aureus isolates, 5 virulence profiles were found; the profile $n u c^{(+)} \operatorname{coa}^{(+)} f n b A^{(+)} i c a A^{(+)} i c a D^{(+)} m e c A^{(-)} m e c C^{(-)}$ $s e a^{(-)} s e b^{(-)}$was the most frequently observed (21 out of 23 dairy farms). No differences were found between the virulence profile frequencies of Staph. aureus from BTM and adherences on milking equipment surfaces. The virulence profiles most frequently observed included genes involved in the adherence and biofilm-forming ability of Staph. aureus, which could represent a potential advantage for the bacterium during the early stages of IMI colonization and for persistence on surfaces. Our results indicate a greater frequency of virulence factors of importance for IMI pathogenesis than virulence factors of public health concern, consistent with the dairy origin of isolates. The $m e c A, m e c C$, and seb genes
\end{abstract}

Received October 28, 2019.

Accepted January 5, 2020.

*Corresponding author: alatorre@udec.cl were not observed among Staph. aureus isolates analyzed in this study. However, the sea gene was detected in 3 Staph. aureus isolated from BTM, thus posing a potential public health threat. Our results emphasize the importance of understanding the epidemiology and dynamics of Staph. aureus on dairy farms as a tool for the improvement of udder health and milk safety.

Key words: Staphylococcus aureus, virulence factor, enterotoxin, biofilm, milking equipment

\section{Short Communication}

Staphylococcus aureus is an important pathogen for both human and animal health. In dairy herds, Staph. aureus is one of the most prevalent intramammary pathogens described around the world, including Chile (Munoz et al., 2018). Although milk from cows suffering from subclinical IMI caused by Staph. aureus may not show macroscopic changes, intramammary infecting bacteria can be shed in the milk and be a source of bulk tank milk (BTM) contamination. Extramammary sources of Staph. aureus, such as biofilms on milking equipment surfaces, can also contribute to BTM contamination (Latorre et al., 2020). Regardless of the initial source of Staph. aureus in milk, the presence of strains carrying genes that confer virulence traits, such as enterotoxin production or antimicrobial resistance, is a public health concern.

Virulence profiles (VP) of IMI caused by Staph. aureus have been previously reported (Åvall-Jääskeläinen et al., 2018). Nevertheless, few studies have assessed VP of Staph. aureus isolated from BTM (Kreausukon et al., 2012; Prenafeta et al., 2014) and, to our knowledge, no previous studies have analyzed the VP of Staph. aureus isolated from biofilms or adherences on milking equipment surfaces (AMES) in contact with milk during milking or milk cooling. The objective of this study was to assess and describe the presence of Staph. aureus virulence factors involved in the pathogenesis of cow IMI as well as virulence factors of concern for human health among Staph. aureus isolates obtained from 
BTM and AMES in Chilean dairy herds. This study represents the first report describing the VP of Staph. aureus isolated from in situ adherences or biofilms in milking equipment, and it is the first $\operatorname{mec} C$ assessment on Staph. aureus obtained from dairy operations reported in Chile.

A total of 166 Staph. aureus isolates collected from 23 dairy farms of the Nuble Region in Chile were analyzed. The 23 farms corresponded to farms that were Staph. aureus positive (i.e., Staph. aureus was isolated at least once from BTM or AMES samples) among 30 farms that voluntarily participated in the study. The 30 farms corresponded to $59 \%$ of active dairy farms in the region that complied with the selection criteria for participation in the study (i.e., farms that had stationary milking equipment and a refrigerated bulk tank for cooling and storage of milk and that did not hand-milk the cows were included). Dairy operations of the study had year-round and seasonal confinement of cows and had grazing systems. The number of lactating cows on the participating farms ranged from 5 to 1,020 cows, with an average of 112 and a median of 48 milking cows per farm. A total of 17 farms (64.8\%) had milking units connected to a milk line, whereas the remaining 6 farms $(35.2 \%)$ had milking units connected to milk cans that were used to collect the milk before it was transferred to the bulk tank for cooling and storage. Bulk tank milk samples were collected during 3 consecutive days on each farm following the National Mastitis Council guidelines (Hogan et al., 1999). Briefly, BTM samples from a single milking were aseptically collected in 100$\mathrm{mL}$ sterile vials once the milk was cooled to refrigeration temperature in the tank and after agitation for at least 10 min. For Staph. aureus analysis, BTM samples were individually cultured in Baird-Parker agar (Oxoid, Basingstoke, UK) as described by Jayarao et al. (2004). In addition, samples of AMES (i.e., visible films or adherences attached to milking equipment surfaces, persisting after cleaning and sanitation procedures) were collected and cultured in ChroMagar Staph aureus (ChroMagar, Paris, France) as described by Latorre et al. (2020). For both BTM and AMES putative Staph. aureus isolates, identification was confirmed by PCR using the methods described by Riffon et al. (2001). Virulence factors assessment was conducted for all 166 Staph. aureus isolates from both BTM $(\mathrm{n}=113)$ and AMES $(\mathrm{n}=53)$. For AMES, the analyzed Staph. aureus included isolates obtained from adherences on rubber liners $(\mathrm{n}=8)$, milk collectors $(\mathrm{n}=4)$, collector valve $(\mathrm{n}$ $=2)$, short milk tube $(\mathrm{n}=2)$, long milk hoses $(\mathrm{n}=4)$, bulk tank outlet (inner and outer area, $\mathrm{n}=4$ ), agitator blades $(\mathrm{n}=2)$, milk cans $(\mathrm{n}=13)$, receiving jar $(\mathrm{n}=$ $2)$, receiving jar cover $(n=2)$, milk hoses used to divert milk from cows with mastitis or undergoing antibiotic treatment $(\mathrm{n}=3)$, and milk line sections $(\mathrm{n}=7)$.

For virulence genes analysis, Staph. aureus isolates were cultured for $6 \mathrm{~h}$ in $\mathrm{BHI}$ at $37^{\circ} \mathrm{C}$, and bacterial DNA was extracted as described by Adwan (2014). Virulence genes analyzed on Staph. aureus isolates were fibronectin A $(f n b A)$, intercellular adhesion A $(i c a A)$ and D (icaD), enterotoxin A (sea) and B (seb), and methicillin resistance (mecA and mecC); the virulence markers coagulase (coa) and thermonuclease (nuc) were also analyzed. Analysis was conducted using the primer sequences and PCR conditions described previously (Murakami et al., 1991; Vasudevan et al., 2003; Vancraeynest et al., 2004; Cremonesi et al., 2005; Srinivasan et al., 2006; Paterson et al., 2012). Negative controls (Staphylococcus epidermidis ATCC 12228 and ultrapure water) and positive controls were included on each PCR run. Staphylococcus aureus ATCC 29213 was used as a positive control for icaA, icaD, fnbA, coa, and $n u c$ genes, whereas 2 reference strains from the Chilean Institute of Public Health, Nunoa, Chile (Staph. aureus SA190 and SA170) were used as positive controls for detection of sea and seb genes, respectively. For methicillin resistance genes, Staph. aureus ATCC 43300 and Staph. aureus mec $\mathrm{A}_{\mathrm{LGA} 251}$ were used as positive controls for detection of mecA and mecC, respectively. Virulence profiles of Staph. aureus isolates were analyzed using descriptive statistics, and difference between the proportion of VP in Staph. aureus from AMES and BTM was analyzed using chi-squared or Fisher's exact analysis.

All Staph. aureus isolates were positive for coa, nuc, and $f n b A$ genes, whereas mecA, mecC, and seb genes were not detected. A total of $5 \mathrm{VP}$ were observed among the Staph. aureus isolates analyzed (Table 1). The VP $n u c^{(+)} \operatorname{coa}^{(+)} f n b A^{(+)} i c a A^{(+)} i c a D^{(+)} m e c A^{(-)}$ $m e c C^{(-)}$sea $^{(-)}$seb $^{(-)}$(VP1) was observed on $90(79.6 \%)$ and $41(77.4 \%)$ of the BTM and AMES isolates, respectively. This VP1 was observed on 21 out of the 23 dairy operations. On dairies where Staph. aureus was isolated from both BTM and AMES $(\mathrm{n}=8)$, this VP1 was observed in all samples (Table 2). The VP $n u c^{(+)} \operatorname{coa}^{(+)}$ $f n b A^{(+)} i c a A^{(-)} i c a D^{(+)} m e c A^{(-)} m e c C^{(-)}$sea $^{(-)}$seb $^{(-)}$was the second VP (VP2) most frequently observed (15.9 and $20.8 \%$ of BTM and AMES Staph. aureus isolates, respectively). Overall, no differences were observed between the source of the isolate (BTM or AMES) and the frequency of VP of Staph. aureus $(P \leq 0.05$; Table 1).

Coagulase and thermonuclease virulence marker gene results are consistent with phenotypic characteristics of Staph. aureus, for which biochemical tests such as nuclease and coagulase test or the presence of these 
Table 1. Virulence profiles (VP) of Staphylococcus aureus isolated from bulk tank milk (BTM) and adherences on milking equipment surfaces (AMES)

\begin{tabular}{|c|c|c|c|c|c|c|c|c|c|c|}
\hline \multirow[b]{2}{*}{ Item } & \multicolumn{3}{|c|}{$\mathrm{VP}^{1}$} & \multicolumn{2}{|c|}{$\operatorname{BTM}(\mathrm{n}=113)$} & \multicolumn{2}{|c|}{$\operatorname{AMES}(\mathrm{n}=53)$} & \multicolumn{2}{|c|}{ Total $(\mathrm{n}=166)$} & \multirow[b]{2}{*}{$P$-value ${ }^{2}$} \\
\hline & $i c a A$ & $i c a D$ & sea & No. & $\%$ & No. & $\%$ & No. & $\%$ & \\
\hline VP1 & + & + & - & 90 & 79.6 & 41 & 77.4 & 131 & 78.9 & 0.74 \\
\hline VP2 & - & + & - & 18 & 15.9 & 11 & 20.8 & 29 & 17.5 & 0.58 \\
\hline VP3 & + & + & + & 3 & 2.7 & 0 & 0.0 & 3 & 1.8 & 0.45 \\
\hline VP4 & - & - & - & 1 & 0.9 & 1 & 1.9 & 2 & 1.2 & 1 \\
\hline VP5 & + & - & - & 1 & 0.9 & 0 & 0.0 & 1 & 0.6 & 0.55 \\
\hline
\end{tabular}

${ }^{1}$ All isolates were $c o a^{(+)} n u c^{(+)} f n b A^{(+)} \operatorname{seb}^{(-)} m e c A^{(-)} m e c C^{(-)}$.

${ }^{2}$ Differences between BTM and AMES were calculated using chi-squared or Fisher's exact test $(P<0.05)$.

genes on putative isolates are commonly used for species identification (Cremonesi et al., 2005; Grispoldi et al., 2019). The $f n b A$ gene was highly conserved among Staph. aureus isolated from BTM and AMES samples in our study $(100 \%)$. This prevalence of $f n b A$ is rather high and contrasts with previous reports. For example, frequencies of $f n b A$ on Staph. aureus among different samples include $43 \%$ on bovine quarter milk with IMI, $28 \%$ on teat skin, $21.4 \%$ on BTM, and $0.8 \%$ on humans (Haveri et al., 2008; da Costa et al., 2014; Khoramian et al., 2015). High fibronectin frequency in our study may be explained by a high incidence of participating farms isolating Staph. aureus in 2 or more consecutive BTM samples, an indication of underlying IMI in the herds (Jayarao et al., 2004). Fibronectin A has been described as an important protein involved in Staph. aureus adhesion to host fibronectin, elastin, and fibrinogen (Kerro Dego et al., 2002). Moreover, internalization of Staph. aureus in bovine and human epithelial cells has been described to be assisted by fibronectin A adhesion (Jett and Gilmore, 2002; Pereyra et al., 2016). Furthermore, the presence of $f n b A$-positive Staph. aureus on AMES in

Table 2. Virulence profiles (VP) of Staphylococcus aureus isolated from bulk tank milk (BTM) and adherences on milking equipment surfaces (AMES) on Chilean dairy farms

\begin{tabular}{|c|c|c|c|c|c|}
\hline \multirow[b]{2}{*}{ Dairy farm } & \multirow[b]{2}{*}{$\mathrm{VP}^{1}$} & \multirow[b]{2}{*}{ VP frequency $(\%)$} & \multicolumn{3}{|c|}{ Source of Staph. aureus ${ }^{2}$} \\
\hline & & & AME CTE & AMES CM & BTM \\
\hline A & VP1, VP2, VP4 & $37.5,50,12.5$ & ND &,,+++ &,,++- \\
\hline B & VP1 & 100 & ND & + & + \\
\hline $\mathrm{C}$ & VP1 & 100 & ND & ND & + \\
\hline $\mathrm{D}$ & VP1 & 100 & ND & ND & + \\
\hline $\mathrm{E}$ & VP1, VP2 & $83.3,16.7$ & ND & ND & + \\
\hline $\mathrm{F}$ & VP1 & 100 & ND & ND & + \\
\hline G & VP1, VP2, VP4 & $33.3,50,16.6$ & ND & ND &,,+++ \\
\hline $\mathrm{H}$ & $\mathrm{VP} 1, \mathrm{VP} 2$ & 60,40 & ND &,++ &,++ \\
\hline I & VP2, VP3 & 25,75 & ND & ND &,++ \\
\hline $\mathrm{J}$ & VP1, VP2 & $91.7,8.3$ &,+- &,++ &,++ \\
\hline $\mathrm{K}$ & VP1 & 100 & ND & ND & + \\
\hline $\mathrm{L}$ & VP2 & 100 & ND & ND & + \\
\hline M & VP1, VP2 & $38.4,61.5$ & ND &,++ &,++ \\
\hline $\mathrm{N}$ & VP1 & 100 & ND & ND & + \\
\hline $\mathrm{O}$ & VP1 & 100 & ND & ND & + \\
\hline $\mathrm{P}$ & VP1 & 100 & ND & + & + \\
\hline Q & VP1, VP2 & $20.0,80.0$ & ND & ND &,++ \\
\hline $\mathrm{R}$ & VP1 & 100 & ND & ND & + \\
\hline $\mathrm{S}$ & VP1 & 100 & ND & ND & + \\
\hline $\mathrm{T}$ & VP1 & 100 & ND & ND & + \\
\hline $\mathrm{U}$ & VP1, VP5 & $85.7,14.3$ & ND &,+- &,++ \\
\hline $\mathrm{V}$ & VP1 & 100 & ND & ND & + \\
\hline W & VP1 & 100 & ND & + & + \\
\hline \multicolumn{6}{|c|}{$\begin{array}{l}{ }^{1} \text { All isolates were } c o a^{(+)} n u c^{(+)} f n b A^{(+)} \operatorname{seb}^{(-)} m e c A^{(-)} m e c C^{(-)} \cdot \mathrm{VP} 1=i c a A^{(+)} i c a D^{(+)} \operatorname{sea}^{(-)} ; \mathrm{VP} 2=i c a A^{(+)} \\
i c a D^{(+)} \operatorname{sea}^{(-)} ; \mathrm{VP} 3=i c a A^{(+)} i c a D^{(+)} \operatorname{sea}^{(+)} ; \mathrm{VP} 4=i c a A^{(-)} i c a D^{(-)} \operatorname{sea}^{(-)} ; \mathrm{VP} 5=i c a A^{(+)} i c a D^{(-)} \operatorname{sea}^{(-)} .\end{array}$} \\
\hline
\end{tabular}


pieces of milking equipment in close contact with teat ends could pose an increased risk for IMI due to a putative improved advantage of $f n b A$-positive Staph. aureus during the attachment phase of IMI pathogenesis.

Most studies assessing $i c a A$ and $i c a D$ are focused on Staph. aureus isolated from milk samples from clinical or subclinical mastitis, with frequencies ranging from 87 to $100 \%$ (Vasudevan et al., 2003; Castelani et al., 2015; Khoramian et al., 2015; Pereyra et al., 2016). However, to our knowledge, no previous reports on icaA and icaD are available for Staph. aureus from AMES, and only a few have been described for BTM isolates (Kreausukon et al., 2012; Prenafeta et al., 2014). Even though the frequency of both genes (78.9\%) among our analyzed isolates is lower than that reported in other studies (Vasudevan et al., 2003; Castelani et al., 2015; Khoramian et al., 2015; Pereyra et al., 2016), the presence of these genes could represent an important mechanism for adhesion to biotic or abiotic surfaces, such as milking equipment surfaces. It is noteworthy that about one-third of our isolates were obtained from adherences or biofilms in milking equipment, which could also be responsible for BTM contamination due to Staph. aureus sloughed from these biofilms (Latorre et al., 2020). Consequently, the findings in our study may be skewed toward the presence of Staph. aureus with increased capabilities for adherence in both milking equipment and BTM. After surface adhesion, the polysaccharide intercellular adhesin, which is codified by the intercellular adhesion operon icaABCD, can be secreted around Staph. aureus (de Souza da Cunha, 2014). Accumulated polysaccharide intercellular adhesion plays a key role in the development of biofilms, which not only contributes to the persistence of pathogens on dairy farms (Latorre et al., 2011) but also confers the bacteria physical protection against the immune system, antimicrobials, and disinfectants that are commonly used in dairy operations. In our study, confirmation of AMES as biofilms (i.e., visualization of both bacteria attached to a surface and the presence of an exopolymeric matrix) was done only in the pieces of milking equipment that could be removed to conduct microscopy analysis (Latorre and Munoz, 2015; Latorre et al., 2020). However, the macroscopic physical properties of AMES in the pieces that were not microscopically assessed were consistent with those in the pieces in which the presence of biofilms was confirmed. Therefore, our results highlight the importance of investigating new sources of Staph. aureus such as adherences or biofilms in milking equipment, which may play a role in animal and human infections due to the close contact of parts and pieces of the equipment with teat ends, milker hands, and milk.

In our study, Staph. aureus virulence factors of public health concern (i.e., antimicrobial resistance and en- terotoxin production genes) were not detected or were observed with low frequency. Only 3 BTM Staph. aureus isolates $(1.8 \%)$, which were obtained from a single dairy operation, were positive for the enterotoxin A gene. Staphylococcal enterotoxins are proteins that can cause enteric diseases and emetic symptoms in people who consume contaminated food with sufficient quantities of staphylococcal enterotoxins, including dairy products (Johler et al., 2018; Necidová et al., 2019). Even though raw milk consumption is not recommended due to the high risk of the presence of foodborne pathogens (Oliver et al., 2005), it is a rather common practice in the rural population of Chile, particularly on dairy farms (Latorre and Munoz, 2013). It is noteworthy that the 3 sea-positive Staph. aureus isolates were recovered from 2 out of 3 BTM samples from a single farm. This finding may represent a serious risk for human health as raw milk consumption has been reported by farm workers on this farm (A. A. Latorre and M. A. Munoz, unpublished data). Even if milk is pasteurized, staphylococcal enterotoxin $\mathrm{A}$ is a heat-stable protein that remains detectable after treatment of milk over $92^{\circ} \mathrm{C}$ (Necidová et al., 2019). Therefore, staphylococcal enterotoxin surveillance is crucial to improve dairy foods safety and protect consumer health (Miao et al., 2017).

Antimicrobial resistance is of great concern for both human and animal health. To our knowledge, this study is the first report of mecA and mecC assessment on Staph. aureus isolated from milk and milking equipment on Chilean dairies. Our results are consistent with other studies conducted in foods in Chile (specifically, in the pork meat supply), in which the absence of both mecC and mecA genes among Staph. aureus isolates has also been described (Velasco et al., 2018). However, methicillin resistance genes mecA and mecC have been previously detected in human and veterinary Staph. aureus isolates in other studies conducted in European countries and Australia (Worthing et al., 2016; Lakhundi and Zhang, 2018).

Although the present study shows the findings obtained in a limited number of farms from a single region of Chile, the diversity of farms of this study (i.e., in terms of the number of milking cows, farm facilities and management, and milk quality parameters) could be found in many dairy operations in Chile as well as on farms from different parts of the world. Moreover, although only a selected proportion of the virulence factors described for Staph. aureus were analyzed in our study, the inclusion of genes involved in adherence and biofilm formation from Staph. aureus isolated from in situ adherences or biofilm contributes to the current knowledge about Staph. aureus on-farm epidemiology. Several questions remain to be addressed, such as the role of the infected mammary gland as one of the po- 
tential sources of Staph. aureus for both AMES and BTM. Nevertheless, genetic relation among Staph. aureus from BTM, AMES, and IMI has recently been well documented in one of the 23 dairy farms of our study (Latorre et al., 2020).

Addressing the emerging importance to assess methicillin-resistant Staph. aureus sources in animal and food production, the present study is the first to evaluate mecA and mecC in Staph. aureus isolates from Chilean dairy operations. Virulence profiles of Staph. aureus isolated from adherences or biofilms on surfaces in contact with milk and BTM were not different despite being obtained from different farm sources. Reservoirs in dairy operations such as biofilms or adherences on surfaces in contact with milk can be a source of Staph. aureus that are capable of invading and infecting the mammary gland.

\section{ACKNOWLEDGMENTS}

Financial support was provided by the Chilean Commission for Scientific and Technological Research, FONDECYT Project No. 11130343, and Chilean Doctoral Fellowship Fund No. 21140108 (Santiago, Chile). We thank the Chilean Institute of Public Health (Nunoa, Chile) for providing positive controls for sea and seb analysis. We also thank Mark Holmes and Ibrahim Ba (Department of Veterinary Medicine, University of Cambridge, Cambridge, UK) for kindly providing positive controls for mec $C$ analysis. The authors have not stated any conflicts of interest.

\section{REFERENCES}

Adwan, K. 2014. Fast DNA isolation and PCR protocols for detection of methicillin-resistant staphylococci. Folia Microbiol. (Praha) 59:5-8. https://doi.org/10.1007/s12223-013-0259-1.

Åvall-Jääskeläinen, S., S. Taponen, R. Kant, L. Paulin, J. Blom, A. Palva, and J. Koort. 2018. Comparative genome analysis of 24 bovine-associated Staphylococcus isolates with special focus on the putative virulence genes. PeerJ 6:e4560. https://doi.org/10.7717/ peerj. 4560 .

Castelani, L., L. E. Pilon, T. Martins, C. R. Pozzi, and J. R. P. Arcaro. 2015. Investigation of biofilm production and icaA and icaD genes in Staphylococcus aureus isolated from heifers and cows with mastitis. Anim. Sci. J. 86:340-344. https://doi.org/10.1111/asj.12284.

Cremonesi, P., M. Luzzana, M. Brasca, S. Morandi, R. Lodi, C. Vimercati, D. Agnellini, G. Caramenti, P. Moroni, and B. Castiglioni. 2005. Development of a multiplex PCR assay for the identification of Staphylococcus aureus enterotoxigenic strains isolated from milk and dairy products. Mol. Cell. Probes 19:299-305. https://doi.org/ 10.1016/j.mcp.2005.03.002.

da Costa, L. B., P. J. Rajala-Schultz, A. Hoet, K. S. Seo, K. Fogt, and B. S. Moon. 2014. Genetic relatedness and virulence factors of bovine Staphylococcus aureus isolated from teat skin and milk. J. Dairy Sci. 97:6907-6916. https://doi.org/10.3168/jds.2014-7972.

de Souza da Cunha, M. L. R. 2014. Staphylococcus aureus and Coagulase-Negative Staphylococci: Virulence, Antimicrobial Resistance and Molecular Epidemiology. Department of Microbiology and Im- munology, Botucatu Biosciences Institute, Univ Estadual Paulista, Botucatu, São Paulo, Brazil.

Grispoldi, L., L. Massetti, P. Sechi, M. F. Iulietto, M. Ceccarelli, M. Karama, P. A. Popescu, F. Pandolfi, and B. T. Cenci-Goga. 2019. Short communication: Characterization of enterotoxin-producing Staphylococcus aureus isolated from mastitic cows. J. Dairy Sci. 102:1059-1065. https://doi.org/10.3168/jds.2018-15373.

Haveri, M., M. Hovinen, A. Roslöf, and S. Pyörälä. 2008. Molecular types and genetic profiles of Staphylococcus aureus strains isolated from bovine intramammary infections and extramammary sites. J. Clin. Microbiol. 46:3728-3735. https://doi.org/10.1128/JCM .00769-08.

Hogan, J. S., R. N. Gonzalez, R. J. Harmon, S. C. Nickerson, S. P. Oliver, J. W. Pankey, and K. L. Smith. 1999. Laboratory Handbook on Bovine Mastitis. National Mastitis Council Inc., Madison, WI.

Jayarao, B. M., S. R. Pillai, A. A. Sawant, D. R. Wolfgang, and N. V. Hegde. 2004. Guidelines for monitoring bulk tank milk somatic cell and bacterial counts. J. Dairy Sci. 87:3561-3573. https://doi.org/ 10.3168/jds.S0022-0302(04)73493-1.

Jett, B. D., and M. S. Gilmore. 2002. Internalization of Staphylococcus aureus by human corneal epithelial cells: Role of bacterial fibronectin-binding protein and host cell factors. Infect. Immun. 70:4697-4700. https://doi.org/10.1128/iai.70.8.4697-4700.2002.

Johler, S., G. Macori, A. Bellio, P. L. Acutis, S. Gallina, and L. Decastelli. 2018. Short communication: Characterization of Staphylococcus aureus isolated along the raw milk cheese production process in artisan dairies in Italy. J. Dairy Sci. 101:2915-2920. https://doi .org/10.3168/jds.2017-13815.

Kerro Dego, O. K., J. E. van Dijk, and H. Nederbragt. 2002. Factors involved in the early pathogenesis of bovine Staphylococcus aureus mastitis with emphasis on bacterial adhesion and invasion. A review. Vet. Q. 24:181-198. https://doi.org/10.1080/01652176.2002 .9695135 .

Khoramian, B., F. Jabalameli, A. Niasari-Naslaji, M. Taherikalani, and M. Emaneini. 2015. Comparison of virulence factors and biofilm formation among Staphylococcus aureus strains isolated from human and bovine infections. Microb. Pathog. 88:73-77. https:// doi.org/10.1016/j.micpath.2015.08.007.

Kreausukon, K., A. Fetsch, B. Kraushaar, K. Alt, K. Müller, V. Krömker, K. H. Zessin, A. Käsbohrer, and B. A. Tenhagen. 2012. Prevalence, antimicrobial resistance, and molecular characterization of methicillin-resistant Staphylococcus aureus from bulk tank milk of dairy herds. J. Dairy Sci. 95:4382-4388. https://doi.org/10.3168/ jds.2011-5198.

Lakhundi, S., and K. Zhang. 2018. Methicillin-resistant Staphylococcus aureus: Molecular characterization, evolution, and epidemiology. Clin. Microbiol. Rev. 31:e00020-18. https://doi.org/10.1128/CMR $.00020-18$.

Latorre, A. A., and M. A. Munoz. 2013. Assessment of on-farm raw milk consumption in Chilean dairy operations. Pages 161-162 in Proc. Natl. Mastitis Counc. Annu. Meeting, San Diego, CA. Natl. Mastitis Counc. Inc., Verona, WI.

Latorre, A. A., and M. A. Munoz. 2015. On-farm evaluation of surfaces in contact with milk during milking as a factor affecting the microbiological quality of bulk tank milk on Chilean dairy farms: A preliminary report. Pages. 231-232 in Proc. Natl. Mastitis Counc. Annu. Meeting, Memphis, TN. Natl. Mastitis Counc. Inc., Verona, WI.

Latorre, A. A., P. A. Pachá, G. González-Rocha, I. San Martín, M. Quezada-Aguiluz, A. Aguayo-Reyes, H. Bello-Toledo, R. Oliva, A. Estay, J. Pugin, and M. A. Muñoz. 2020. On-farm surfaces in contact with milk: The role of Staphylococcus aureus-containing biofilms for udder health and milk quality. Foodborne Pathog. Dis. 17:44-51. https://doi.org/10.1089/fpd.2019.2704.

Latorre, A. A., J. A. S. Van Kessel, J. S. Karns, M. J. Zurakowski, A. K. Pradhan, K. J. Boor, E. Adolph, S. Sukhnanand, and Y. H. Schukken. 2011. Increased in vitro adherence and on-farm persistence of predominant and persistent Listeria monocytogenes strains in the milking system. Appl. Environ. Microbiol. 77:36763684. https://doi.org/10.1128/AEM.02441-10. 
Miao, J., Y. Liang, L. Chen, W. Wang, J. Wang, B. Li, L. Li, D. Chen, and Z. Xu. 2017. Formation and development of Staphylococcus biofilm: With focus on food safety. J. Food Saf. 37:e12358. https:/ /doi.org/10.1111/jfs.12358.

Munoz, M., C. Acuña, F. Sáez, A. Latorre, and B. León. 2018. Antimicrobial resistance profiles of microorganisms isolated from milk samples from clinical mastitis and subclinical-infected quarters in dairy herds from Chile. Pages $184-185$ in Proc. Natl. Mastitis Counc. Annu. Meeting, Tucson, AZ. Natl. Mastitis Counc. Inc., Verona, WI.

Murakami, K., W. Minamide, K. Wada, E. Nakamura, H. Teraoka, and S. Watanabe. 1991. Identification of methicillin-resistant strains of staphylococci by polymerase chain reaction. J. Clin. Microbiol. 29:2240-2244. https://doi.org/10.1128/JCM.29.10.2240 $-2244.1991$

Necidová, L., Š. Bursová, D. Haruštiaková, K. Bogdanovičová, and I. Lačanin. 2019. Effect of heat treatment on activity of staphylococcal enterotoxins of type A, B, and C in milk. J. Dairy Sci. 102:3924-3932. https://doi.org/10.3168/jds.2018-15255.

Oliver, S. P., B. M. Jayarao, and R. A. Almeida. 2005. Foodborne pathogens in milk and the dairy farm environment: Food safety and public health implications. Foodborne Pathog. Dis. 2:115-129. https://doi.org/10.1089/fpd.2005.2.115.

Paterson, G. K., A. R. Larsen, A. Robb, G. E. Edwards, T. W. Pennycott, G. Foster, D. Mot, K. Hermans, K. Baert, S. J. Peacock, J. Parkhill, R. N. Zadoks, and M. A. Holmes. 2012. The newly described mecA homologue, mecALGA251, is present in methicillinresistant Staphylococcus aureus isolates from a diverse range of host species. J. Antimicrob. Chemother. 67:2809-2813. https://doi .org/10.1093/jac/dks329.

Pereyra, E. A. L., F. Picech, M. S. Renna, C. Baravalle, C. S. Andreotti, R. Russi, L. F. Calvinho, C. Diez, and B. E. Dallard. 2016. Detection of Staphylococcus aureus adhesion and biofilm-producing genes and their expression during internalization in bovine mammary epithelial cells. Vet. Microbiol. 183:69-77. https://doi.org/10 $.1016 /$ j.vetmic.2015.12.002.

Prenafeta, A., M. Sitjà, M. A. Holmes, and G. K. Paterson. 2014. Short communication: Biofilm production characterization of $m e c A$ and mecC methicillin-resistant Staphylococcus aureus isolated from bovine milk in Great Britain. J. Dairy Sci. 97:4838-4841. https://doi .org/10.3168/jds.2014-7986.
Riffon, R., K. Sayasith, H. Khalil, P. Dubreuil, M. Drolet, and J. Lagacé. 2001. Development of a rapid and sensitive test for identification of major pathogens in bovine mastitis by PCR. J. Clin. Microbiol. 39:2584-2589. https://doi.org/10.1128/JCM.39.7.2584 $-2589.2001$.

Srinivasan, V., A. A. Sawant, B. E. Gillespie, S. J. Headrick, L. Ceasaris, and S. P. Oliver. 2006. Prevalence of enterotoxin and toxic shock syndrome toxin genes in Staphylococcus aureus isolated from milk of cows with mastitis. Foodborne Pathog. Dis. 3:274-283. https://doi.org/10.1089/fpd.2006.3.274.

Vancraeynest, D., K. Hermans, and F. Haesebrouck. 2004. Genotypic and phenotypic screening of high and low virulence Staphylococcus aureus isolates from rabbits for biofilm formation and MSCRAMMs. Vet. Microbiol. 103:241-247. https://doi.org/10 .1016/j.vetmic.2004.09.002.

Vasudevan, P., M. K. M. Nair, T. Annamalai, and K. S. Venkitanarayanan. 2003. Phenotypic and genotypic characterization of bovine mastitis isolates of Staphylococcus aureus for biofilm formation. Vet. Microbiol. 92:179-185. https://doi.org/10.1016/S0378 -1135(02)00360-7.

Velasco, V., J. L. Vergara, A. M. Bonilla, J. Muñoz, A. Mallea, D. Vallejos, M. Quezada-Aguiluz, J. Campos, and P. Rojas-García. 2018. Prevalence and characterization of Staphylococcus aureus strains in the pork chain supply in Chile. Foodborne Pathog. Dis. 15:262-268. https://doi.org/10.1089/fpd.2017.2381.

Worthing, K. A., G. W. Coombs, S. Pang, S. Abraham, S. Saputra, D. J. Trott, D. Jordan, H. S. Wong, R. J. Abraham, and J. M. Norris. 2016. Isolation of mecC MRSA in Australia. J. Antimicrob. Chemother. 71:2348-2349. https://doi.org/10.1093/jac/dkw138.

\section{ORCIDS}

P. A. Pacha @ https://orcid.org/0000-0001-7786-0891

M. A. Munoz $\odot$ https://orcid.org/0000-0003-2401-3749

E. Paredes-Osses $\odot$ https://orcid.org/0000-0002-9432-4203

A. A. Latorre (ㄴ) https://orcid.org/0000-0002-8544-6073 